\title{
Economic Feasibility Analysis in Developing 5G Infrastructure and Locations in Indonesia
}

\author{
Yudha Aprilianto, Muhammad Asrol, Fergyanto E Gunawan \\ Industrial Engineering Department, BINUS Graduate Program - \\ Master of Industrial Engineering, Bina Nusantara University, Jakarta, 11480, Indonesia
}

\begin{abstract}
Indonesia is preparing advanced telecommunication services, $5 \mathrm{G}$ technology, to provide the best service for the internet users. The objective of the research is to find feasible regions in developing $5 \mathrm{G}$ technology in Indonesia. The regional selection was carried out by combining Analytical Hierarchy Process (AHP) and Composite Performance Index (CPI). Further, the economic feasibility of the selected locations was evaluated using NPV, IRR and PBP technique. The result found that the potential cities to develop the $5 \mathrm{G}$ technology in Indonesia were Jakarta, Surabaya, and Bandung. Economic feasibility evaluations showed that Jakarta and Bandung were the most feasible cities for the first 5G technology development in the future.
\end{abstract}

Keywords- Analytic hierarchy process, Composite performance index, Feasibility, Telecommunication, 5G technology.

\section{Introduction}

The rapid development of cellular telecommunication technology in Indonesia is proof by the use of smartphones as a necessity for the community. The history of mobile telecommunication technology has evolved starting

DOI: $10.18421 /$ TEM101-15

https://doi.org/10.18421/TEM101-15

Corresponding author: Muhammad Asrol,

Industrial Engineering Department, BINUS Graduate Program - Master of Industrial Engineering, Bina Nusantara University, Jakarta, 11480, Indonesia.

Email: muhammad.asrol@binus.edu

Received: 27 November 2020.

Revised: 16 January 2021.

Accepted: 21 January 2021.

Published: 27 February 2021.

(c) BY-NC-ND (C) 2021 Yudha Aprilianto, Muhammad Asrol \& Fergyanto E Gunawan; published by UIKTEN. This work is licensed under the Creative Commons AttributionNonCommercial-NoDerivs 4.0 License.

The article is published with Open Access at www.temjournal.com from $1 \mathrm{G}$ and followed by the next $2 \mathrm{G}, 3 \mathrm{G}, 4 \mathrm{G}$ and $5 \mathrm{G}$ technologies. The term $\mathrm{G}$ or Generation means the development of technological innovation in human life. Currently, cellular telecommunications services have entered the era of $4 \mathrm{G}$ (four-generation) internet technology. The growth of internet users in Indonesia is growing very fast, it was recorded that the growth of active internet users in 2018 was $64.8 \%$ of the total population or increase up to $10 \%$ compared to the previous year. The largest users were on the Java island (55\%), then followed by Sumatra (21\%), Sulawesi- Maluku-Papua areas (10\%), Kalimantan (9\%), and Bali and Nusa Tenggara (5\%) [1].

It differs from 4G, 5th generation (5G) technology is so superior in speed, able to complement, fill gaps, and improve current $4 \mathrm{G}$ technology. Later, 5G technology will be integrated into smartphone technology, big data, internet of things (IoT), cloud computing and supporting digital transformation in various socio-economic sectors including health, smart cars, smart homes, automation industry, finance and others. This technology is supported by the advantages of low latency, real-time communication, and more efficient battery usage [2].

Indonesia also joins another country to adopt this technology and implement it in recently. The various conditions above require the readiness of the Indonesian government and the telecommunications industry in planning the provision of $5 \mathrm{G}$ cellular technology services. Several things that have to be considered are developing the planning agenda of this program which include network testing, frequency spectrum slots, infrastructure development, and potential market [3].

For those reasons, as the pilot project of this technology, government and industry have to decide which area to be implemented first. Therefore, the selection of infrastructure development areas is the subject of this research. The importance of selecting the area of implementing 5G technology is based on demographics, high investment costs for equipment, the availability of existing infrastructure networks, the behavior of community needs in using 
telecommunications technology services, and several other factors [4]. These aspects are regulated in government regulations regarding technical guidelines for the location of telecommunications towers which have several criteria based on priority order as follows: population density, cost, distance, and access.

The intense competition, especially the tariff war among telecommunication industry in Indonesia, required to provide affordable technology services with the best quality to customers. This is a challenge for the telecommunications industry because customer expectations are inversely proportional to the increasingly expensive investment in the procurement of telecommunications technology equipment [5]. When business competition is getting tighter, effective management and strategic decision making are required. Therefore, the determination of locations and the feasibility study of the 5G technology implementation are very important to achieve an efficient and competitive price. These requirements have to fulfill to develop an effective and efficient result and the technology which is able to provide the best service for the consumer. By collaborating the several factors above, it will be easier for business people, especially the telecommunications industry, to get the right area as well so that they get benefits and a good experience for customers.

The objective of the research is to determine the specific location of $5 \mathrm{G}$ technology implementation in Indonesia and provides the economic feasibility assessment. This research provides a potential location to develop 5G technology based on expert assessment, quantitative measurement and economic feasibility study. This paper is organized as follows: in these sections the research background and research objective are described. The following sections are literature review, methods, result and discussion and conclusions. The framework and supporting theory are described in the literature review. The research stages, framework and the tool analysis are presented at the methods. The result of the analysis and the interpretation of the result is provided at the result and discussion. Finally, the conclusion and recommendation are provided with the general result to answer the research objective.

\section{Literature Review}

\section{G Technology}

By 2025 it is estimated that 25 billion devices will be connected to $5 \mathrm{G}$ technology [6]. The history of telecommunication technology began with the first generation $(1 \mathrm{G})$ technology to bring consumers the first mobile phones. Service phones are expensive, and basic analog networks offer voice-only service with limited coverage and capacity. The secondgeneration $(2 \mathrm{G})$ technology uses a digital network, which supports voice and SMS with a wider range. The third-generation $(3 \mathrm{G})$ technology supports voice, data, and cellular access to the internet (email and video). At this time smartphones were introduced, and people started using cell phones as computers for business and entertainment, as well as the increasing demand for data services. The fourth-generation $(4 \mathrm{G})$ technology offers increased speed, and mobile broadband can support streaming music and video, mobile applications, and online games. Telecommunication operators offer unlimited data plans and mobile devices that can be used as hotspots to connect from other devices to the network, thereby increasing demand for cellular data. Then, the fifthgeneration (5G) technology which uses new technology to provide faster speeds, greater capacity, and improved services. The $5 \mathrm{G}$ network is expected to meet the growing demand for data from consumers, and to support new services. $5 \mathrm{G}$ is also designed to meet the growing demand for data from industrial users, and to support the growing use of mobile communication technology in various industries ( plant management systems, public safety applications, and new medical technologies) [3].

The targets obtained in 5G technology planning, in general, are high data rates (1-10 Gbps), latency below $1 \mathrm{~ms}$, cost and energy-efficient, having a capacity of 1000 times than the current capacity, wide coverage using heterogeneous networks, and stable connectivity [7]. 5G technology is very suitable for the development and changes in the industry today, especially industry 4.0. Industry generation 4.0 requires communication technology that has to meet specific industry needs with network infrastructure, time, heterogeneity, safety and security. Several requirements such as industryspecific cycle times and production processes underlie the utilization of this technology. Typically, the utility and food industries are less critical and require a cycle time of around $100 \mathrm{~ms}$. Automotive and heavy equipment production requires a typical cycle time of $10 \mathrm{~ms}$. The highest demand is determined by motion control applications that require a latency of less than $1 \mathrm{~ms}$ [8].

Besides, industrial developments that will be based on $5 \mathrm{G}$ technology will be closely related to creative applications so that they can encourage the utilization of technology. Inseparable from technological developments, this push can be a necessity, for example, in this case, the GoJek phenomenon. GoJek is a transportation startup service in Indonesia which is a social innovation by applying supply chain management science, where the creation of content or applications (innovation) is based on desire, so that things can run more efficiently and easier [9]. 


\section{Analytical Hierarchy Process (AHP)}

The Analytical Hierarchy Process (AHP) was developed by Thomas Lorie Saaty to find a priority order of various alternatives in problem-solving. In the routine of human life, several alternative options are always encountered in solving a problem [10]. It is also necessary to determine priorities and test the consistency of the choices that have been taken or decided. In a very complex problem situation, decision making is not only influenced by one factor but also by various types of factors.

In AHP, policy priority setting is done by rationally capturing people's perceptions, then converting intangible factors into ordinary rules, so that they can be compared. In this study, the selection of criteria used the AHP method with the following stages [11].

a. Identifying problems and determining the expected solution. This identification is carried out by studying references and discussing with experts who understand the problems so that concepts that are relevant to the problems to be studied will be obtained.

b. The next stage is the preparation of a hierarchical structure by determining objectives and criteria. Perform pairwise comparisons, describing the relative influence of each element on each of the objectives or criteria above it. The pairwise comparison technique used in AHP is based on "judgments" or the opinions of respondents or experts who are considered to be "key persons" through primary data collection or questionnaires. Before the pairwise comparisons, the value was determined to the results of the criteria comparison questionnaire by several experts. The formula for determining the geometric mean is found in Equation 1.

$$
\mathrm{MG}=\sqrt[n]{\sum_{i=1}^{n} x i}
$$

$\mathrm{MG}=$ Geometric Mean

$\mathrm{xi}=$ Alternative to-

$\mathrm{n}=$ Number of data

c. Normalize data by dividing each paired matrix element value by the total value in each column.

d. Calculating the eigenvector value and testing the level of consistency, and if inconsistent results are obtained. It is done by repeating the data collection process. This eigenvector value is the maximum eigenvector value obtained through Matlab or manual calculations. Besides, we also calculate the weight of each pairwise comparison matrix.

e. Hierarchy consistency testing is conducted, if the value obtained is more than $10 \%$, then the data judgment has to be corrected. Vice versa, if the consistency ratio (CR) is less than $0.1(\mathrm{CR} \leq$ 0.1 ), then the calculation results can be concluded that it is correct. The ratio consistency formula can be seen in Equation 2.

$$
\mathrm{CR}=\frac{\mathrm{CI}}{\mathrm{RI}}
$$

$\mathrm{CR}=$ Consistency Ratio

$\mathrm{CI}=$ Consistency Index

$\mathrm{RI}=$ Index Random Consistency

$$
\mathrm{CI}=\frac{\left(\lambda_{\max }-\mathrm{n}\right)}{\mathrm{n}-1}
$$

$\lambda \max =$ The maximum eigenvalues of the pairwise comparison matrix

$\mathrm{n} \quad=$ Number of elements

Index random consistency (RI) [12].

\begin{tabular}{||cccc||}
\hline $\begin{array}{c}\text { Number of } \\
\text { Criteria }\end{array}$ & RI Value & $\begin{array}{c}\text { Number of } \\
\text { Criteria }\end{array}$ & RI Value \\
1 & 0.00 & 9 & 1.45 \\
2 & 0.00 & 10 & 1.49 \\
3 & 0.58 & 11 & 1.51 \\
4 & 0.90 & 12 & 1.48 \\
5 & 1.12 & 13 & 1.56 \\
6 & 1.24 & 14 & 1.57 \\
7 & 1.32 & 15 & 1.59 \\
8 & 1.41 & & \\
\hline
\end{tabular}

\section{Composite Performance Index (CPI)}

The Composite Performance Index (CPI) is a composite index that can be used to determine the assessment or ranking of various alternatives (i) based on several criteria (j). The composite performance index method is also a model for calculating the performance index-based decision making and can be used to provide an assessment of various criteria [13].

This method is quite easy to implement manually or in combination with other methods so that one will get decision results from various criteria and good alternatives [14]. Besides, the CPI method developed for sustainability can be useful for assessing industrial performance and identifying socio-economic environmental problems [15].

The following is the calculation procedure using the CPI method [16]:

a. Identifying the criteria for positive trends (the higher the value the better), negative trends (the lower the value the better), and categorizing the data types.

b. In criteria categorized as a trend $(+)$, it is transformed to one hundred for the minimum value for each criterion, while the other values are transformed proportionally higher. The calculation of trend $(+)$ can be seen in Equation 3. 


$$
\text { Trend }(+)=\frac{\mathrm{N} \text { Value }}{\text { Min.value }} \times 100
$$

c. The criteria categorized as a trend (-) are transformed to one hundred for the minimum value for each criterion, while the other values are transformed proportionally lower. The calculation of trend (-) can be seen in Equation 4.

$$
\text { Trend (-) }=\frac{\text { Min.value }}{\text { N value }} \times 100
$$

d. The calculation of creative value is the sum of the multiplication of the criterion value with the criterion weight and the ranking of the total alternative value.

\section{Research Method}

In implementing new technology, problems in planning are often faced, especially in deciding which area to be implemented. Indonesia, which is an archipelagic country with large cities, is a challenge for the telecommunications industry. This research composes a scientific framework for the implementation of the $5 \mathrm{G}$ technology to provide an effective and efficient business. The research framework is given in Figure 1.

To provide a detailed phase of the research framework above, the research stages are presented in Figure 2.

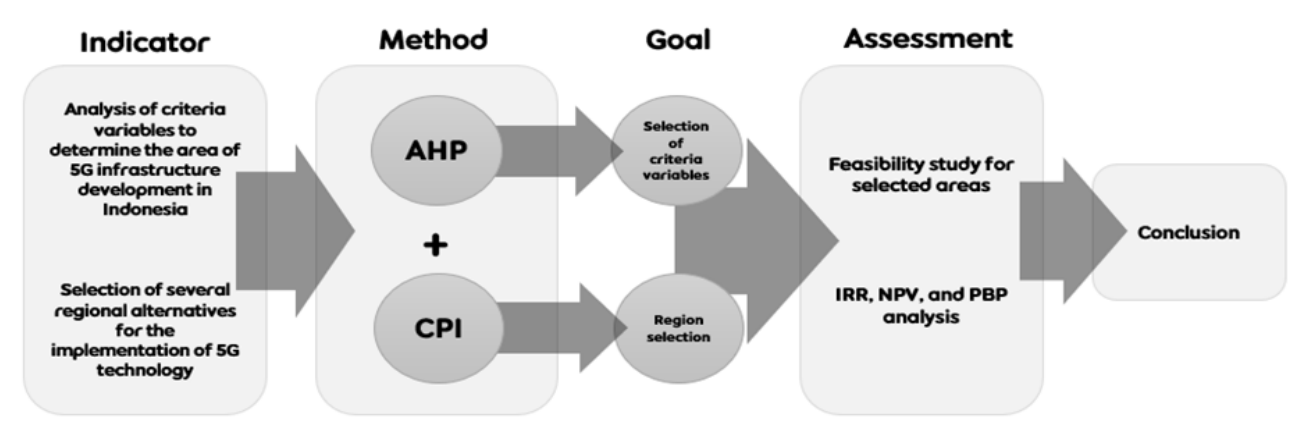

Figure 1. Research framework

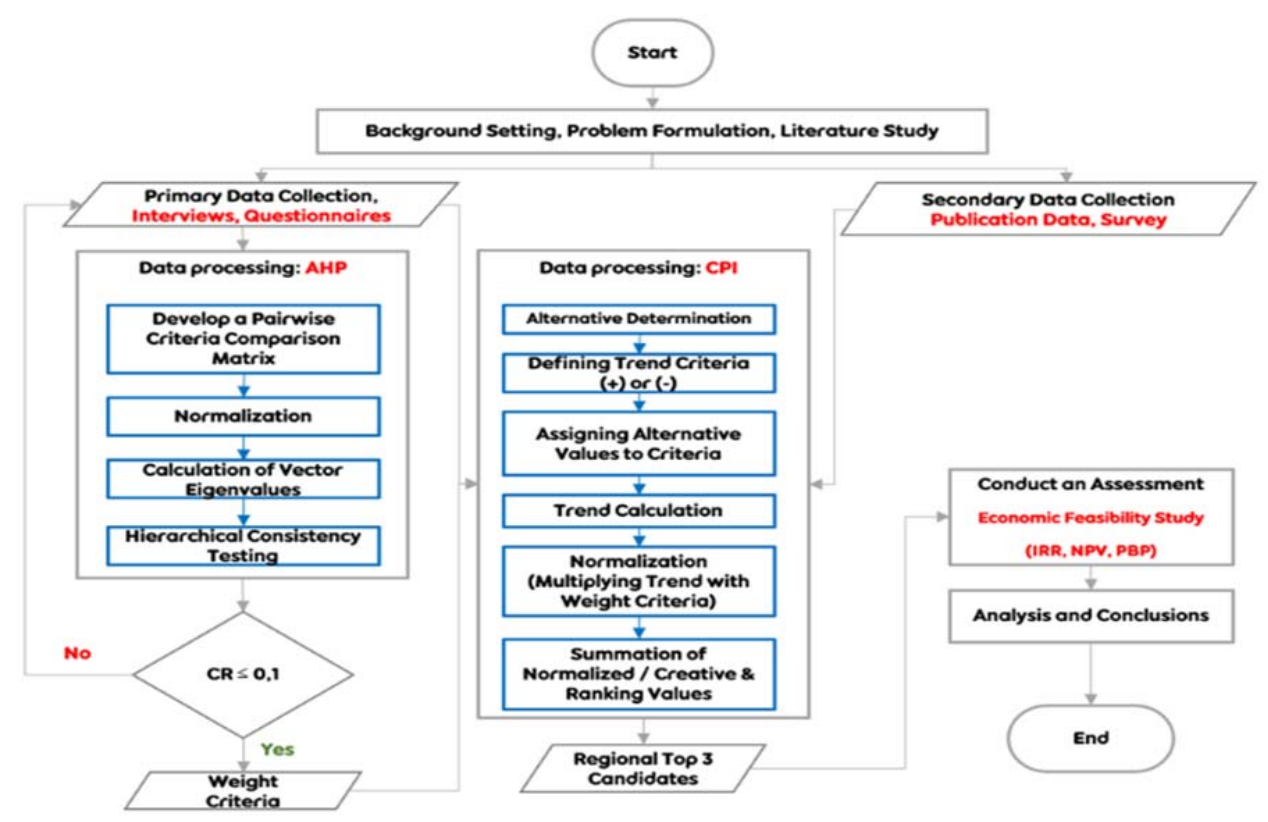

Figure 2. Research stage

The research stages are divided into 3 parts, namely data collection, data analysis using Analytical Hierarchy Process (AHP) and Composite Performance Index (CPI) to determine a location to develop a $5 \mathrm{G}$ technology and economic-feasibility analysis to provide detail information of each location. The detail of each stag is described as follows:

a. Data Collection Stage
Data collection in this study consisted of primary and secondary data. Primary data were obtained through questionnaires and in-depth interviews with expert respondents who could provide accurate information [17]. Interviews and questionnaires were conducted to Subject Matter Experts (SME) in telecommunications and $5 \mathrm{G}$ technology expert. The details of the subject matter experts (SME) are described in Table 1. 
Table 1. Subject matter experts

\begin{tabular}{ccc}
\hline No & Professional background & Amount \\
\hline 1 & Tower Provider & 1 \\
2 & Sehuler Operators & 7 \\
3 & Academics & 1 \\
4 & Government & 1 \\
\hline & Total & $\mathbf{1 0}$ \\
\hline
\end{tabular}

b. Determine 5G technology locations using AHP and CPI

In the AHP method, policy priority setting is done by capturing people's perceptions rationally, then converting intangible (unmeasured) factors into ordinary rules, so they can be compared. In selecting $5 \mathrm{G}$ technology locations, the AHP method is used to determine the weight of the criteria. The objectives and required criteria can be described in the AHP hierarchy in Figure 3.

The criteria weight results obtained by the AHP method will be used for the calculation process and the trending value multiplier for each alternative specified in the CPI method. The alternative areas in question include Jakarta, Bandung, Semarang, Yogyakarta, Surabaya, Denpasar, Medan and Makassar. The final results of the AHP and CPI methods will be obtained by ranking of the alternative areas.

c. Economic-feasibility analysis

The main objective of investing is to obtain a high profit or return. A project or business feasibility study is an activity to evaluate, analyze, and assess whether or not a business project is feasible to run [18]. A feasibility study is needed before the implementation of a business, this is used as a consideration in making decisions. Several quantitative methods are used to determine investment eligibility standards:

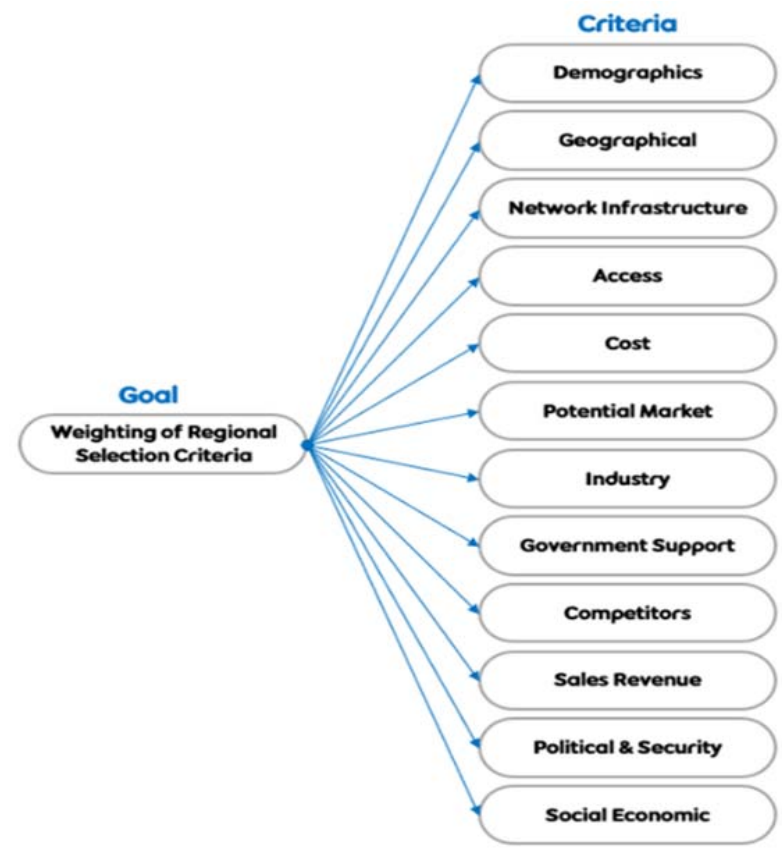

Figure 3. Structure hierarchy $A H P$
Net Present Value (NPV), the net profit is calculated from the difference between the present value of the investment and the present value of the expected net cash flow receipts from the project or investment in the future or a certain period [19]. The NPV formula can be seen in Equation 5.

$$
\begin{aligned}
& \mathrm{NPV}=\left(-\mathrm{CF}_{0}\right)+\sum_{\mathrm{t}=1}^{\mathrm{n}} \frac{\mathrm{CF}_{\mathrm{t}}}{(1+\mathrm{r})^{\mathrm{t}}} \\
& \text { CF0 = Initial investment year } 0 \text { (initial cost } \\
& \text { incurred to invest in the project) } \\
& \mathrm{CFt}=\text { Cash flow generated during the specified } \\
& \text { period (year } \mathrm{t} \text { ) } \\
& r=\text { Discount rate } \\
& \mathrm{t}=\text { Year } \mathrm{t} \\
& \mathrm{n}=\text { The final period of the expected cash flow }
\end{aligned}
$$

Internal Rate Return (IRR), the investment rate is the interest rate at which all net cash flow is multiplied by the discounted factor or present value, which equals the cost of investment. The IRR value can be calculated by finding the interest rate (discounted rate) which will produce NVP equal to zero [20]. The IRR formula can be seen in Equation 6.

$$
\begin{aligned}
& \mathrm{IRR}=\mathrm{i}_{1}+\frac{\mathrm{NPV}_{1}}{\left(\mathrm{NPV}_{1}-\mathrm{NPV}_{2}\right)}\left(\mathrm{i}_{2}-\mathrm{i}_{1}\right) \\
& \mathrm{i}_{1}=\text { The first interest rate that will produce a } \\
& \text { positive NPV } \\
& \mathrm{i}_{2}=\text { The second interest rate that will result in a } \\
& \text { negative NPV } \\
& \mathrm{NPV} 1=\text { Net Present Value (NPV) (+) } \\
& \text { NPV2 }=\text { Net Present Value (NPV) (-) }
\end{aligned}
$$

Pay Back Period (PBP), the period required to recoup the investment issued (initial cash investment) using cash flow or a period that shows the length of return on capital invested in the project implementation [21].

\section{Result and Discussion}

\section{Analysis of the criteria to determine the locations of $5 G$ implementation}

There are huge criteria to determine an effective location for the implementations of the $5 \mathrm{G}$ technology. An AHP is a powerful technique to determine the criteria based on expert assessment. AHP develop a hierarchy to analyze the criteria and provide the weighted value. As mentioned in the method, there are 12 criteria to consider in determining the locations of 5G technology development in Indonesia.

Through interviews and questionnaires, criteria data are compared and evaluated by experts, so that accurate primary data is obtained according to the topic under study. Primary data can be presented in Table 2. 
Table 2. Primary data for processing the AHP method

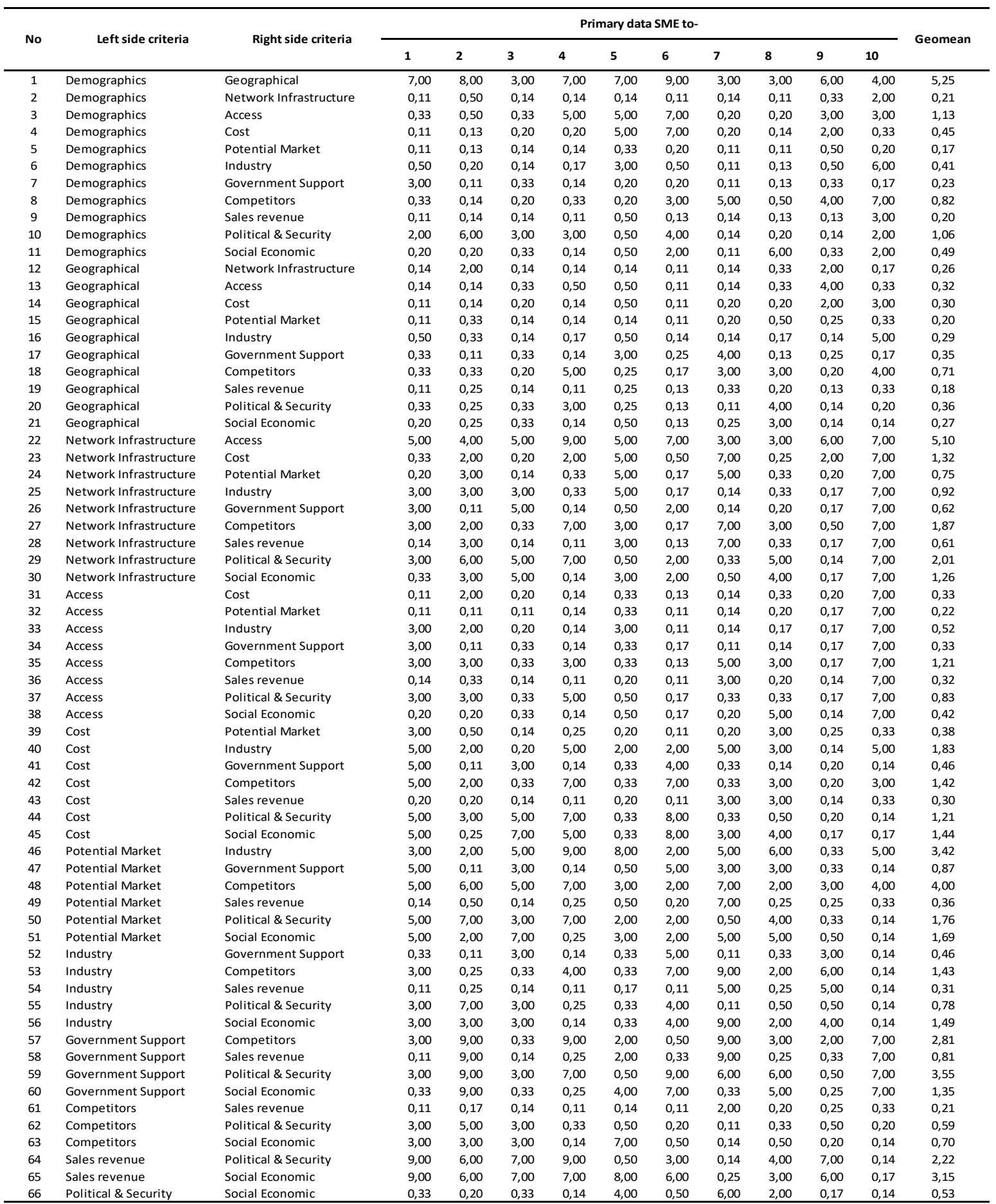

From the data that has been obtained above, it is compiled in a pairwise comparison matrix whose results were shown in Table 3. The next step is to normalize each value from the pairwise comparison matrix by dividing the total value of each criterion column, the results of which can be seen in Table 4 so that the eigenvector value can be obtained. This eigenvector value will later become the weight input of the criteria which functions as a multiplier in the data processing using the CPI method.

Before stepping into processing with the CPI method, checking the calculation and consistency of the hierarchy follows, done by dividing the value of the consistency index $(\mathrm{CI})$ to the index random consistency (RI).

The consistency index (CI) can be obtained from the calculation below.

$$
\mathrm{CI}=\frac{\left(\lambda_{\max }-\mathrm{n}\right)}{\mathrm{n}-1}=\frac{(12,48-12)}{12-1}=0.06
$$

While the index random consistency (RI) value was obtained from the Table, which in this research used 12 criteria so that the RI value is 1.48 from the Table.

$$
\mathrm{CR}=\frac{\mathrm{CI}}{\mathrm{RI}}=\frac{0.06}{1.48}=0.042
$$


Table 3. Pairwise comparison matrix

\begin{tabular}{|c|c|c|c|c|c|c|c|c|c|c|c|c|}
\hline Criteria & Demographics & Geographical & $\begin{array}{c}\text { Network } \\
\text { Infrastructure }\end{array}$ & Access & Cost & Potential Market & Industry & $\begin{array}{c}\text { Government } \\
\text { support }\end{array}$ & Competitors & Sales revenue & $\begin{array}{c}\text { Political \& } \\
\text { Security }\end{array}$ & Social Economic \\
\hline Demographics & 1 & 5,2532 & 0,2128 & 1,1335 & 0,4538 & 0,1725 & 0,4143 & 0,2339 & 0,8175 & 0,2006 & 1,0584 & 0,4929 \\
\hline Geographical & 0,1904 & 1 & 0,2610 & 0,3220 & 0,3007 & 0,1995 & 0,2940 & 0,3500 & 0,7117 & 0,1813 & 0,3564 & 0,2727 \\
\hline $\begin{array}{c}\text { Network } \\
\text { Infrastructure }\end{array}$ & 4,6992 & 3,8308 & 1 & 5,1001 & 1,3222 & 0,7490 & 0,9162 & 0,6165 & 1,8670 & 0,6084 & 2,0050 & 1,2589 \\
\hline Access & 0,8823 & 3,1052 & 0,1961 & 1 & 0,3347 & 0,2180 & 0,5249 & 0,3321 & 1,2070 & 0,3165 & 0,8336 & 0,4169 \\
\hline Cost & 2,2036 & 3,3254 & 0,7563 & 2,9878 & 1 & 0,3780 & 1,8332 & 0,4608 & 1,4171 & 0,3007 & 1,2089 & 1,4421 \\
\hline Potential Market & 5,7971 & 5,0120 & 1,3351 & 4,5881 & 2,6456 & 1 & 3,4154 & 0,8723 & 4,0037 & 0,3606 & 1,7568 & 1,6877 \\
\hline Industry & 2,4140 & 3,4017 & 1,0915 & 1,9052 & 0,5455 & 0,2928 & 1 & 0,4595 & 1,4310 & 0,3064 & 0,7800 & 1,4871 \\
\hline Government support & 4,2755 & 2,8574 & 1,6219 & 3,0109 & 2,1700 & 1,1464 & 2,1761 & 1 & 2,8093 & 0,8123 & 3,5540 & 1,3521 \\
\hline Competitors & 1,2232 & 1,4051 & 0,5356 & 0,8285 & 0,7057 & 0,2498 & 0,6988 & 0,3560 & 1 & 0,2085 & 0,5949 & 0,6983 \\
\hline Sales revenue & 4,9854 & 5,5171 & 1,6438 & 3,1598 & 3,3254 & 2,7730 & 3,2638 & 1,2311 & 4,7953 & 1 & 2,2206 & 3,1469 \\
\hline Political \& Security & 0,9449 & 2,8058 & 0,4987 & 1,1996 & 0,8272 & 0,5692 & 1,2821 & 0,2814 & 1,6808 & 0,4503 & 1 & 0,5319 \\
\hline Social Economic & 2,0288 & 3,6665 & 0,7943 & 2,3985 & 0,6935 & 0,5925 & 0,6724 & 0,7396 & 1,4321 & 0,3178 & 1,8799 & 1 \\
\hline Total & 30,6443 & 41,1802 & $\mathbf{9 , 9 4 7 2}$ & 27,6340 & 14,3243 & 8,3406 & 16,4912 & 6,9333 & 23,1726 & 5,0633 & 17,2485 & 13,7876 \\
\hline
\end{tabular}

Table 4. Normalization of the pairwise comparison matrix value

\begin{tabular}{|c|c|c|c|c|c|c|c|c|c|c|c|c|c|}
\hline Criteria & Demographics & Geographical & $\begin{array}{c}\text { Network } \\
\text { Infrastructure }\end{array}$ & Access & Cost & Potential Market & Industry & $\begin{array}{c}\text { Government } \\
\text { support }\end{array}$ & Competitors & Sales revenue & $\begin{array}{c}\text { Political \& } \\
\text { Security }\end{array}$ & Social Economic & TOTAL \\
\hline Demographics & 0,0326 & 0,1276 & 0,0214 & 0,0410 & 0,0317 & 0,0207 & 0,0251 & 0,0337 & 0,0353 & 0,0396 & 0,0614 & 0,0358 & 0,5058 \\
\hline Geographical & 0,0062 & 0,0243 & 0,0262 & 0,0117 & 0,0210 & 0,0239 & 0,0178 & 0,0505 & 0,0307 & 0,0358 & 0,0207 & 0,0198 & 0,2886 \\
\hline $\begin{array}{c}\text { Network } \\
\text { Infrastructure }\end{array}$ & 0,1533 & 0,0930 & 0,1005 & 0,1846 & 0,0923 & 0,0898 & 0,0556 & 0,0889 & 0,0806 & 0,1202 & 0,1162 & 0,0913 & 1,2663 \\
\hline Access & 0,0288 & 0,0754 & 0,0197 & 0,0362 & 0,0234 & 0,0261 & 0,0318 & 0,0479 & 0,0521 & 0,0625 & 0,0483 & 0,0302 & 0,4825 \\
\hline Cost & 0,0719 & 0,0808 & 0,0760 & 0,1081 & 0,0698 & 0,0453 & 0,1112 & 0,0665 & 0,0612 & 0,0594 & 0,0701 & 0,1046 & 0,9248 \\
\hline Potential Market & 0,1892 & 0,1217 & 0,1342 & 0,1660 & 0,1847 & 0,1199 & 0,2071 & 0,1258 & 0,1728 & 0,0712 & 0,1019 & 0,1224 & 1,7169 \\
\hline Industry & 0,0788 & 0,0826 & 0,1097 & 0,0689 & 0,0381 & 0,0351 & 0,0606 & 0,0663 & 0,0618 & 0,0605 & 0,0452 & 0,1079 & 0,8155 \\
\hline Government support & 0,1395 & 0,0694 & 0,1631 & 0,1090 & 0,1515 & 0,1374 & 0,1320 & 0,1442 & 0,1212 & 0,1604 & 0,2060 & 0,0981 & 1,6318 \\
\hline Competitors & 0,0399 & 0,0341 & 0,0538 & 0,0300 & 0,0493 & 0,0299 & 0,0424 & 0,0513 & 0,0432 & 0,0412 & 0,0345 & 0,0506 & 0,5003 \\
\hline Sales revenue & 0,1627 & 0,1340 & 0,1652 & 0,1143 & 0,2322 & 0,3325 & 0,1979 & 0,1776 & 0,2069 & 0,1975 & 0,1287 & 0,2282 & 2,2778 \\
\hline Political \& Security & 0,0308 & 0,0681 & 0,0501 & 0,0434 & 0,0577 & 0,0682 & 0,0777 & 0,0406 & 0,0725 & 0,0889 & 0,0580 & 0,0386 & 0,6949 \\
\hline Social Economic & 0,0662 & 0,0890 & 0,0799 & 0,0868 & 0,0484 & 0,0710 & 0,0408 & 0,1067 & 0,0618 & 0,0628 & 0,1090 & 0,0725 & 0,8949 \\
\hline Total & 1,00 & 1,00 & 1,00 & 1,00 & 1,00 & 1,00 & 1,00 & 1,00 & 1,00 & 1,00 & 1,00 & 1,00 & 12,00 \\
\hline
\end{tabular}

Table 5. The results of weighting criteria using the AHP

\begin{tabular}{lcc}
\hline \multicolumn{1}{c}{ Criteria } & Weight & Trend \\
\hline Demographics & 0.0422 & Positive \\
Geographical & 0.0240 & Negative \\
Network Infrastructure & 0.1055 & Positive \\
Access & 0.0402 & Positive \\
Cost & 0.0771 & Negative \\
Potential Market & 0.1431 & Positive \\
Industry & 0.0680 & Positive \\
Government Support & 0.1360 & Positive \\
Competitors & 0.0417 & Negative \\
Sales Revenue & 0.1898 & Positive \\
Political \& Security & 0.0579 & Positive \\
Social Economic & 0.0746 & Positive \\
\hline
\end{tabular}

Based on the above calculations, the CR (consistency ratio) value is $\leq 0.1$, so the results of data collection and processing are stated to be consistent. From the calculation of the AHP method above, the results of the weighted criteria are obtained which can be seen in Table 5 .

\section{Determine the specific locations using CPI}

To support the calculation process using the CPI method, an assessment of alternative data and criteria obtained from primary (questionnaire) and secondary (literature study) data was carried out as described in Table 6. 
Following the principles of the CPI method, trending was also carried out against the criteria factors which can be seen in Table 5 .

For the criteria attribute that is categorized as a trend $(+)$, it is transformed to one hundred for the minimum value for each criterion, while other values are transformed proportionally higher. On the other hand, criteria categorized as a trend (-) are transformed to one hundred for the minimum value for each criterion, while the other values are transformed proportionally lower. Processing and the results of these calculations can be seen in Table 7 . The next step is to multiply the AHP criterion weight by the trending value for each value in Table 7, and results can be seen in Table 8 and Figure 4.

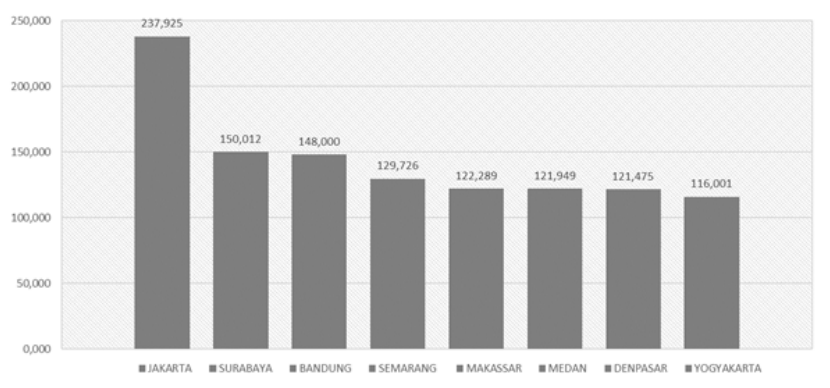

Figure 4. The final value of the alternative area with the CPI method
In Table 8 and Figure 4, we can obtain the ranking order of the final values for regional elections, namely Jakarta, Surabaya, Bandung, Semarang, Medan, Makassar, Denpasar and Yogyakarta. We obtained three major areas that were used as proposals for the development of 5G technology infrastructure, namely Jakarta, Surabaya, and Bandung.

\section{Regional Economic Feasibility Analysis}

In a business investment process, it is not enough only to determine the area of the implementation plan, but also an analysis of its economic feasibility. There are differences in the parameters of the economic feasibility analysis of a company with other companies, this is due to the policies of each company due to differences in types of business. Three main factors are the same in analyzing economic feasibility, namely Capital expenditure (CAPEX), Operational expenditure (OPEX), and revenue [22]. In this research, an analysis of economic feasibility was carried out on the three regions that had the highest value in the calculation of the decision support system analysis above. An overview of the economic feasibility analysis planning method can be seen in Figure 5.

Table 6. Primary data and secondary data for processing the CPI method

\begin{tabular}{|c|c|c|c|c|c|c|c|c|c|c|c|c|c|}
\hline Region & Demographics & Geographical & $\begin{array}{c}\text { Network } \\
\text { Infrastructure }\end{array}$ & Access & Cost & $\begin{array}{l}\text { Potential } \\
\text { Market }\end{array}$ & Industry & $\begin{array}{c}\text { Government } \\
\text { support }\end{array}$ & Competitors & Sales revenue & $\begin{array}{c}\text { Political \& } \\
\text { Security }\end{array}$ & & Social Economic \\
\hline JAKARTA & $11.100 .929,00$ & 2 & 5 & 5 & 4 & 5 & 4 & 4 & 4 & 5 & & 3 & 4 \\
\hline BANDUNG & $2.490 .386,00$ & 3 & 5 & 5 & 4 & 4 & 4 & 4 & & 5 & & 4 & 4 \\
\hline SEMARANG & $1.681 .058,00$ & 2 & 4 & 4 & 3 & 4 & 4 & 4 & 4 & 4 & & 3 & 4 \\
\hline YOGYAKARTA & $414.919,00$ & 2 & 3 & 5 & 4 & 5 & 4 & 4 & & 4 & & 3 & 4 \\
\hline SURABAYA & $2.959 .082,00$ & 3 & 5 & 5 & 4 & 5 & 4 & 4 & & 4 & & 4 & 4 \\
\hline DENPASAR & $651.201,00$ & 2 & 3 & 5 & 4 & 5 & 5 & 4 & & 4 & & 5 & 3 \\
\hline MEDAN & $2.520 .416,00$ & 2 & 3 & 4 & 4 & 4 & 4 & 3 & & 3 & & 3 & 4 \\
\hline MAKASSAR & $1.484 .912,00$ & 2 & 3 & 4 & 4 & 4 & 4 & 4 & 4 & 4 & & 3 & 4 \\
\hline
\end{tabular}

Table 7. The results of the calculation of trending criteria

\begin{tabular}{|c|c|c|c|c|c|c|c|c|c|c|c|c|}
\hline Region & Demographics & Geographical & $\begin{array}{c}\text { Network } \\
\text { Infrastructure }\end{array}$ & Access & Cost & $\begin{array}{r}\text { Potential } \\
\text { Market }\end{array}$ & Industry & $\begin{array}{c}\text { Government } \\
\text { support }\end{array}$ & Competitors & Sales revenue & $\begin{array}{c}\text { Political \& } \\
\text { Security }\end{array}$ & Social Economic \\
\hline JAKARTA & 2675,4448 & 100,0000 & 166,6667 & 125,0000 & 75,0000 & 125,0000 & 100,0000 & 133,3333 & 100,0000 & 166,6667 & 100,0000 & 133,3333 \\
\hline BANDUNG & 600,2102 & 66,6667 & 166,6667 & 125,0000 & 75,0000 & 100,0000 & 100,0000 & 133,3333 & 100,0000 & 166,6667 & 133,3333 & 133,3333 \\
\hline SEMARANG & 405,1533 & 100,0000 & 133,3333 & 100,0000 & 100,0000 & 100,0000 & 100,0000 & 133,3333 & 100,0000 & 133,3333 & 100,0000 & 133,3333 \\
\hline YOGYAKARTA & 100,0000 & 100,0000 & 100,0000 & 125,0000 & 75,0000 & 125,0000 & 100,0000 & 133,3333 & 100,0000 & 133,3333 & 100,0000 & 133,3333 \\
\hline SURABAYA & 713,1710 & 66,6667 & 166,6667 & 125,0000 & 75,0000 & 125,0000 & 100,0000 & 133,3333 & 100,0000 & 133,3333 & 133,3333 & 133,3333 \\
\hline DENPASAR & 156,9465 & 100,0000 & 100,0000 & 125,0000 & 75,0000 & 125,0000 & 125,0000 & 133,3333 & 100,0000 & 133,3333 & 166,6667 & 100,0000 \\
\hline MEDAN & 607,4477 & 100,0000 & 100,0000 & 100,0000 & 75,0000 & 100,0000 & 100,0000 & 100,0000 & 100,0000 & 100,0000 & 100,0000 & 133,3333 \\
\hline MAKASSAR & 357,8800 & 100,0000 & 100,0000 & 100,0000 & 75,0000 & 100,0000 & 100,0000 & 133,3333 & 100,0000 & 133,3333 & 100,0000 & 133,3333 \\
\hline
\end{tabular}


Table 8. The result of multiplying the trending value with the criterion weight value

\begin{tabular}{lcccccccccccccc}
\hline \multicolumn{1}{c}{ Region } & Demographics & Geographical & $\begin{array}{c}\text { Network } \\
\text { Infrastructure }\end{array}$ & Access & Cost & $\begin{array}{c}\text { Potential } \\
\text { Market }\end{array}$ & Industry & $\begin{array}{c}\text { Government } \\
\text { support }\end{array}$ & Competitors & Sales revenue & $\begin{array}{c}\text { Political \& } \\
\text { Security }\end{array}$ & $\begin{array}{c}\text { Social Economic } \\
\text { Total }\end{array}$ \\
\hline JAKARTA & 112,7763 & 2,4047 & 17,5878 & 5,0259 & 5,7800 & 17,8845 & 6,7958 & 18,1312 & 4,1689 & 31,6358 & 5,7906 & 9,9430 & 237,9245 \\
BANDUNG & 25,3003 & 1,6031 & 17,5878 & 5,0259 & 5,7800 & 14,3076 & 6,7958 & 18,1312 & 4,1689 & 31,6358 & 7,7208 & 9,9430 & 148,0002 \\
SEMARANG & 17,0782 & 2,4047 & 14,0702 & 4,0207 & 7,7066 & 14,3076 & 6,7958 & 18,1312 & 4,1689 & 25,3087 & 5,7906 & 9,9430 & 129,7262 \\
YOGYAKARTA & 4,2152 & 2,4047 & 10,5527 & 5,0259 & 5,7800 & 17,8845 & 6,7958 & 18,1312 & 4,1689 & 25,3087 & 5,7906 & 9,9430 & 116,0011 \\
SURABAYA & 30,0618 & 1,6031 & 17,5878 & 5,0259 & 5,7800 & 17,8845 & 6,7958 & 18,1312 & 4,1689 & 25,3087 & 7,7208 & 9,9430 & 150,0115 \\
DENPASAR & 6,6157 & 2,4047 & 10,5527 & 5,0259 & 5,7800 & 17,8845 & 8,4948 & 18,1312 & 4,1689 & 25,3087 & 9,6510 & 7,4573 & 121,4752 \\
MEDAN & 25,6054 & 2,4047 & 10,5527 & 4,0207 & 5,7800 & 14,3076 & 6,7958 & 13,5984 & 4,1689 & 18,9815 & 5,7906 & 9,9430 & 121,9492 \\
MAKASSAR & 15,0855 & 2,4047 & 10,5527 & 4,0207 & 5,7800 & 14,3076 & 6,7958 & 18,1312 & 4,1689 & 25,3087 & 5,7906 & 9,9430 & 122,2893 \\
\hline
\end{tabular}

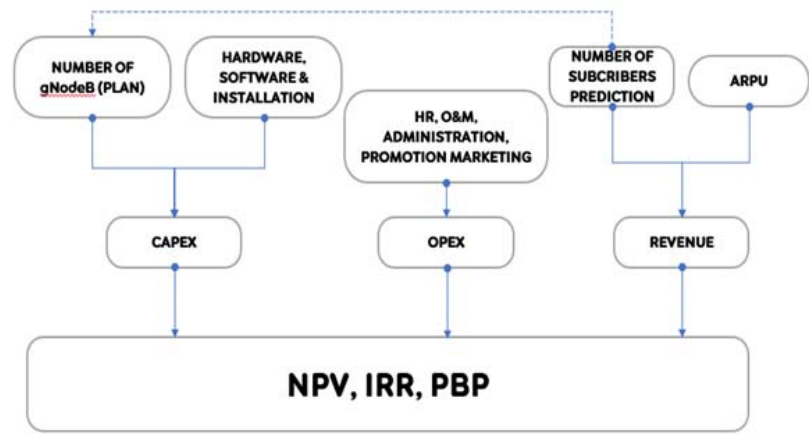

Figure 5. Economic feasibility analysis framework

Several parameter assumptions were also established for this analysis which is represented the telecommunications industry in Indonesia. Investment planning is determined in five years between 2021 and 2025. The frequency spectrum applied to $5 \mathrm{G}$ technology varies widely, some of which are $28 \mathrm{GHz}, 26 \mathrm{GHz}$, and $3.5 \mathrm{GHz}$ [23]. Currently, there is no official stipulation from the Indonesian government that regulates the placement of the $5 \mathrm{G}$ service frequency, therefore this paper apply $3.5 \mathrm{GHz}$ frequency. It is based on the direction of the Indonesian government to carry out technical tests of $5 \mathrm{G}$ technology devices in the $3.5 \mathrm{GHz}$ frequency spectrum, whose ecosystems have been used in several countries that were already implemented $5 \mathrm{G}$ services.

The components in the preparation of the CAPEX budget in this study include the procurement of hardware, software, installation commissioning, and procurement of backhaul for the transmission network. The components in the preparation of the OPEX budget for the development of $5 \mathrm{G}$ infrastructure include promotion and marketing costs, administrative costs, operational and maintenance costs, and human resource costs. Promotion and marketing costs are set at $2 \%$ of the CAPEX value. The administrative fee is set at $1 \%$ of the CAPEX value. Operational and maintenance costs are set at $3 \%$ of the CAPEX value. Human resource costs are the estimated salaries of personnel assigned to $5 \mathrm{G}$ implementation projects in a selected region.
Revenue planning for an investment in the telecommunications industry can be obtained from the average revenue per user (ARPU) value and the prediction of the number of subscribers or users of 5G service users in the selected area [24]. The revenue calculation formula can be calculated using Equation 7.

Revenue $=$ User Prediction $\mathrm{x}$ ARPU

Determining the budget for implementing $5 \mathrm{G}$ technology cannot be separated from the planned number of gNodeB (5G base stations) to be built in the selected area. The calculation of the number of gNodeB is based on the prediction of the number of customers to be served as well as the average population density of an area. The population density of the selected areas can be seen in Table 9.

Table 9. The population density of the selected areas

\begin{tabular}{lr}
\hline \multicolumn{1}{c}{ City } & $\begin{array}{c}\text { Population density } \\
\text { (People/Km }\end{array}$ \\
\hline Jakarta & 16.718 \\
Surabaya & 8.441 \\
Bandung & 14.853 \\
\hline
\end{tabular}

Source: Kemendagri RI, 2020

Table 10. The number of gNodeB 2021 - 2025

\begin{tabular}{lccccc}
\hline \multirow{2}{*}{ City } & \multicolumn{5}{c}{ The Number of gNodeB Year to- } \\
\cline { 2 - 6 } & $\mathbf{2 0 2 1}$ & $\mathbf{2 0 2 2}$ & $\mathbf{2 0 2 3}$ & $\mathbf{2 0 2 4}$ & $\mathbf{2 0 2 5}$ \\
\hline Jakarta & 8 & 24 & 44 & 41 & 24 \\
Surabaya & 4 & 13 & 23 & 22 & 12 \\
Bandung & 2 & 6 & 11 & 10 & 6 \\
\hline
\end{tabular}

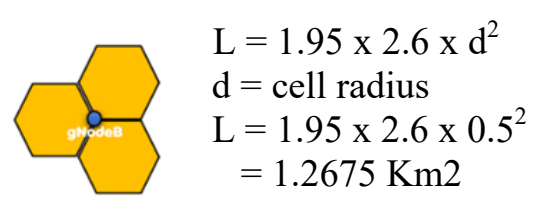

The coverage area of the three sectors of $5 \mathrm{G}$ technology in the $3.5 \mathrm{GHz}$ frequency spectrum is assumed to be able to serve areas with the calculation of Equation 8 [25]. 
It is estimated that the number of users of $5 \mathrm{G}$ technology services is around $40 \%$ of the population density per $\mathrm{km}^{2}$. So, the calculation of the number of gNodeB can be obtained with Equation 9 and the results can be seen in Table 10 .

Num. gNodeB $=\frac{\text { Subscribers prediction }}{\text { coverage area }}$

From the results of data processing, economic calculations will be obtained for each region as presented in Table 11, Table 12 and Table 13. By using the economic investment calculation data, the NPV, IRR and PBP values are obtained, and they are presented in Table 14.

Based on the economic feasibility analysis of the three selected areas, the results show that Jakarta and Bandung are the most economically viable cities for the construction of the first $5 \mathrm{G}$ infrastructure in Indonesia.

Table 11. Economic investment calculations for the Jakarta area 2021 - 2025

\begin{tabular}{|c|c|c|c|c|c|c|c|c|c|c|c|}
\hline NO & KOMPONEN & & 2021 & & 2022 & & 2023 & & 2024 & & 2025 \\
\hline 1 & CAPEX & IDR & 5.314 .988 .152 & IDR & 15.565.322.445 & IDR & 28.473 .150 .814 & IDR & 26.574 .940 .760 & IDR & 15.185 .680 .434 \\
\hline 2 & OPEX & IDR & 1.380 .826 .666 & IDR & 2.257 .373 .845 & IDR & 3.509 .033 .977 & IDR & 4.446.018.215 & IDR & 4.528 .182 .642 \\
\hline 3 & BANK INTEREST $(7.5 \% *$ CAPEX) & IDR & - & IDR & 1.167 .399 .183 & IDR & 2.135 .486 .311 & IDR & 1.993 .120 .557 & IDR & 1.138 .926 .033 \\
\hline 4 & DEPRECIATION & IDR & - & IDR & 1.257.917.942 & IDR & 1.850 .870 .279 & IDR & 1.307.293.076 & IDR & 626.971 .514 \\
\hline 5 & TOTAL COST $(2+3+4)$ & IDR & 1.380 .826 .666 & IDR & 4.682 .690 .970 & IDR & 7.495 .390 .567 & IDR & 7.746 .431 .847 & IDR & 6.294 .080 .189 \\
\hline 6 & REVENUE & IDR & 5.512 .500 .000 & IDR & 21.223 .125 .000 & IDR & 49.160 .475 .000 & IDR & 74.118 .870 .000 & IDR & 87.163 .791 .120 \\
\hline 7 & EBIT-Earning before interest tax (6-5) & IDR & 4.131 .673 .334 & IDR & 16.540 .434 .030 & IDR & 41.665 .084 .433 & IDR & 66.372 .438 .153 & IDR & 80.869 .710 .931 \\
\hline 8 & TAX $(20 \% *$ EBIT $)$ & IDR & - & IDR & 3.308 .086 .806 & IDR & 8.333 .016 .887 & IDR & 13.274 .487 .631 & IDR & 16.173 .942 .186 \\
\hline 9 & EAT -Earning after tax (7-8) & IDR & 4.131 .673 .334 & IDR & 13.232.347.224 & IDR & 33.332 .067 .547 & IDR & 53.097 .950 .522 & IDR & 64.695 .768 .745 \\
\hline 10 & PROCEEDS (9-1) & -IDR & 1.183 .314 .818 & -IDR & 2.332 .975 .221 & IDR & 4.858 .916 .732 & IDR & 26.523 .009 .762 & IDR & 49.510 .088 .310 \\
\hline
\end{tabular}

Table 12. Economic investment calculations for the Surabaya area 2021 - 2025

\begin{tabular}{|c|c|c|c|c|c|c|c|c|c|c|c|}
\hline NO & KOMPONEN & & 2021 & & 2022 & & 2023 & & 2024 & & 2025 \\
\hline 1 & CAPEX & IDR & 1.357 .655 .726 & IDR & 8.463 .495 .486 & IDR & 7.273 .155 .673 & IDR & 6.788 .278 .628 & IDR & 3.879 .016 .359 \\
\hline 2 & OPEX & IDR & 1.146 .198 .734 & IDR & 1.524 .431 .795 & IDR & 1.764 .046 .318 & IDR & 1.998 .654 .202 & IDR & 2.054 .197 .895 \\
\hline 3 & BANK INTEREST $(7.5 \% *$ CAPEX) & IDR & - & IDR & 634.762 .161 & IDR & 545.486 .675 & IDR & 509.120 .897 & IDR & 290.926 .227 \\
\hline 4 & DEPRECIATION & IDR & - & IDR & 676.136 .036 & IDR & 467.362 .069 & IDR & 330.103 .738 & IDR & 158.316 .176 \\
\hline 5 & TOTAL $\operatorname{cosT}(2+3+4)$ & IDR & 1.146 .198 .734 & IDR & 2.835 .329 .993 & IDR & 2.776 .895 .063 & IDR & 2.837 .878 .837 & IDR & 2.503 .440 .297 \\
\hline 6 & REVENUE & IDR & 1.236.676.032 & IDR & 4.761 .202 .722 & IDR & 11.028 .676 .852 & IDR & 16.627 .851 .253 & IDR & 19.554.353.074 \\
\hline 7 & EBIT-Earning before interest tax (6-5) & IDR & 90.477 .298 & IDR & 1.925 .872 .730 & IDR & 8.251 .781 .788 & IDR & 13.789.972.416 & IDR & 17.050.912.776 \\
\hline 8 & TAX $(20 \% *$ EBIT $)$ & IDR & - & IDR & 385.174 .546 & IDR & 1.650 .356 .358 & IDR & 2.757 .994 .483 & IDR & 3.410 .182 .555 \\
\hline 9 & EAT -Earning after tax (7-8) & IDR & 90.477 .298 & IDR & 1.540 .698 .184 & IDR & 6.601 .425 .431 & IDR & 11.031 .977 .933 & IDR & 13.640 .730 .221 \\
\hline 10 & PROCEEDS (9-1) & -IDR & 1.267 .178 .428 & -IDR & 6.922 .797 .302 & -IDR & 671.730 .242 & IDR & 4.243 .699 .305 & IDR & 9.761 .713 .862 \\
\hline
\end{tabular}

Table 13. Economic investment calculations for the Bandung area 2021 - 2025

\begin{tabular}{|c|c|c|c|c|c|c|c|c|c|c|c|}
\hline NO & KOMPONEN & & 2021 & & 2022 & & 2023 & & 2024 & & 2025 \\
\hline 1 & CAPEX & IDR & 2.852 .461 .180 & IDR & 8.353 .636 .314 & IDR & 15.281 .042 .038 & IDR & 14.262.305.902 & IDR & 8.149 .889 .087 \\
\hline 2 & OPEX & IDR & 1.200 .465 .106 & IDR & 1.557 .411 .524 & IDR & 2.088 .310 .167 & IDR & 2.426 .600 .209 & IDR & 2.554 .559 .093 \\
\hline 3 & BANK INTEREST $(7.5 \% *$ CAPEX) & IDR & - & IDR & 626.522 .724 & IDR & 1.146 .078 .153 & IDR & 1.069 .672 .943 & IDR & 611.241 .682 \\
\hline 4 & DEPRECIATION & IDR & - & IDR & 665.380 .642 & IDR & 979.025 .112 & IDR & 691.497 .813 & IDR & 331.639 .048 \\
\hline 5 & TOTAL COST $(2+3+4)$ & IDR & 1.200 .465 .106 & IDR & 2.849 .314 .889 & IDR & 4.213 .413 .432 & IDR & 4.187.770.965 & IDR & 3.497 .439 .822 \\
\hline 6 & REVENUE & IDR & 1.472 .231 .250 & IDR & 5.668 .090 .313 & IDR & 13.129.358.288 & IDR & 19.795.032.495 & IDR & 23.278 .958 .214 \\
\hline 7 & EBIT-Earning before interest tax (6-5) & IDR & 271.766 .144 & IDR & 2.818 .775 .423 & IDR & 8.915 .944 .856 & IDR & 15.607 .261 .530 & IDR & 19.781.518.392 \\
\hline 8 & TAX $(20 \% *$ EBIT $)$ & IDR & - & IDR & 563.755 .085 & IDR & 1.783 .188 .971 & IDR & 3.121 .452 .306 & IDR & 3.956 .303 .678 \\
\hline 9 & EAT -Earning after tax (7-8) & IDR & 271.766 .144 & IDR & 2.255 .020 .339 & IDR & 7.132 .755 .885 & IDR & 12.485 .809 .224 & IDR & 15.825 .214 .713 \\
\hline 10 & PROCEEDS (9-1) & -IDR & 2.580 .695 .037 & -IDR & 6.098 .615 .975 & -IDR & 8.148 .286 .153 & -IDR & 1.776 .496 .677 & IDR & 7.675 .325 .627 \\
\hline
\end{tabular}


Table 14. The results of the economic feasibility analysis of the NPV, IRR, PBP

\begin{tabular}{|c|c|c|c|c|c|}
\hline \multirow{2}{*}{ CITY } & \multicolumn{4}{|c|}{ ECONOMIC FEASIBILITY ANALYSIS } & \multirow{2}{*}{ ASSESMENT } \\
\hline & & NPV & IRR & PBP & \\
\hline JAKARTA & IDR & $58.268 .474 .080,09$ & $209,8 \%$ & 2 Years 11 Months & FEASIBLE \\
\hline SURABAYA & -IDR & $10.982 .050 .591,35$ & $-31,1 \%$ & 5 Years 4 Months & NOT FEASIBLE \\
\hline BANDUNG & IDR & $2.290 .860 .089,50$ & $18,0 \%$ & 3 Years 10 Months & FEASIBLE \\
\hline
\end{tabular}

\section{Conclusion}

This research provides a complete analysis to determine feasible locations to develop an efficient $5 \mathrm{G}$ technology in Indonesia. There are 12 criteria to consider in determining the locations. Expert and quantitative data are analyzed using AHP and CPI technique and find three cities to consider in developing 5G technology, namely Jakarta, Bandung, and Surabaya. Further, based on a feasibility study, Jakarta and Bandung are the most viable cities to develop the $5 \mathrm{G}$ technology in the future based on specific criteria. Jakarta has NPV value IDR. 58.268.474.080,09; IRR value is $209.8 \%$ and the payback period is 2 years 11 months while Bandung has the NPV value is IDR. 2.290.860.089,50; IRR value is $18.0 \%$ and the payback period is 3 years 10 months.

For further research, to provide an efficient analysis, the model and technique in this research need to be implemented in a Decision Support System (DSS). The DSS will possibly provide a quick analysis to assist managers to decide which locations and criteria to be considered in developing $5 \mathrm{G}$ technology in the future.

\section{References}

[1]. APJII. (2019). “Buletin APJII Edisi-40” p.6, Retrieved from: https://apjii.or.id/survei. [accessed: 15 June 2020].

[2]. Mourad, M., Galal, N. M., \& El Sayed, A. E. (2012). Optimal location-allocation of automatic teller machines. In Conference: World Academy of Science, Engineering and Technology (Vol. 61).

[3]. Gallagher, J. C., \& DeVine, M. E. (2019). Fifthgeneration $(5 \mathrm{G})$ telecommunications technologies: issues for congress. Congressional Research Service, 1(30), 1-39. doi: 10.1155/2019/5710834.

[4]. Soepomo, P. (2014). Sistem Pendukung Keputusan Penentuan Lokasi Pembangunan Tower Base Transceiver Station (Bts) Menggunakan Kriteria Bayes Yang Disertai Letak Geografisnya. JSTIE (Jurnal Sarj. Tek. Inform.), 3(1), 20-31.

[5]. Tim Peneliti Puslitbang SDPPI. (2018). Analisa Industri Telekomunikasi Indonesia untuk Mendukung Efisiensi. Badan Penelitian dan Pengembangan SDM, Kementerian Komunikasi dan Informatika.
[6]. GSMA. (2018), “Mobile Economy 2018," GSMA Intell. Retrieved from:

https://www.gsmaintelligence.com/. [accessed: 19 September 2020].

[7]. Docomo, N. T. T. (2014). 5G radio access: Requirements, concept and technologies. white paper.

[8]. Rao, S. K., \& Prasad, R. (2018). Impact of 5G technologies on industry 4.0. Wireless personal communications, 100(1), 145-159.

[9]. Admaja, A. F. S. (2015). Kajian Awal 5G Indonesia [5G Indonesia Early Preview]. Buletin Pos dan Telekomunikasi, 13(2), 97-114.

[10]. Reisi, M., Afzali, A., \& Aye, L. (2018). Applications of analytical hierarchy process (AHP) and analytical network process (ANP) for industrial site selections in Isfahan, Iran. Environmental earth sciences, 77(14), 1-13.

[11]. Darmanto, E., Latifah, N., \& Susanti, N. (2014). Penerapan metode AHP (Analythic Hierarchy Process) untuk menentukan kualitas gula tumbu. Simetris: Jurnal Teknik Mesin, Elektro Dan Ilmu Komputer, 5(1), 75-82.

[12]. Alonso, J. A., \& Lamata, M. T. (2006). Consistency in the analytic hierarchy process: a new approach. International Journal of Uncertainty, Fuzziness and Knowledge-Based Systems, 14(04), 445-459. doi: 10.1142/S0218488506004114.

[13]. Nugroho, A., \& Bahtiar, N. (2016). Sistem Pendukung Keputusan Penentuan Nilai Kenaikan Pangkat Tni Angkatan Darat Menggunakan Metode Composite Performance Index (Cpi). Matematika, 19(3), 102-108.

[14]. Rossanty, Y., Hasibuan, D., Napitupulu, J., Nasution, M. D. T. P., \& Rahim, R. (2018). Composite performance index as decision support method for multi case problem. Int. J. Eng. Technol, 7(2.29), 3336.

[15]. Pandian, G. S., Jawahar, N., \& Nachiappan, S. P. (2013). Composite performance index for sustainability. IOSR Journal of Environmental Science, Toxicology and Food Technology, 3(1), 91102.

[16]. Rahim, R., Mesran, M., Siahaan, A. P. U., \& Aryza, S. (2017). Composite Performance Index for Student Admission. International Journal of Research In Science \& Engineering, 3(3).

[17]. Megel, M. E., \& Heermann, J. A. (1994). Methods of data collection. Plastic surgical nursing: official journal of the American Society of Plastic and Reconstructive Surgical Nurses, 14(2), 109-110. 
[18]. Afiyah, A., \& Dwiatmoko, M.S. (2015). Analisis Studi Kelayakan Usaha Pendirian Home Industry (Studi Kasus pada Home Industry Cokelat "Cozy" Kademangan Blitar). Jurnal Administrasi Bisnis (JAB), 23(1).

[19]. Arshad, A. (2012). Net present value is better than internal rate of return. Interdisciplinary journal of contemporary research in business, 4(8), 211-219.

[20]. Arjunan, K. (2017). IRR Performs Better than NPV: A Critical Analysis of Cases of Multiple IRR and Mutually Exclusive and Independent Investments. Revised and updated version as of, 23.

[21]. Al-Ani, M. K. (2015). A strategic framework to use payback period in evaluating the capital budgeting in energy and oil and gas sectors in Oman. International journal of economics and financial issues, 5(2), 469475.
[22]. Utama, R. Y. (2016). Analisis Tekno Ekonomi Kelayakan Migrasi Jaringan 2G/3G ke 4G LTE Pada Frekuensi $900 \mathrm{MHz}$ dan $1800 \mathrm{MHz}$ di DKI Jakarta (Studi Kasus: PT. Indosat, Tbk) (Doctoral dissertation, Universitas Mercu Buana).

[23]. Hikmaturokhman, A., Ramli, K., \& Suryanegara, M. (2019). On Developing a New 5G Spectrum Usage Fee Model for Indonesia. International Journal on Advanced Science Engineering Information Technology, 9(6), 1968-1975.

[24]. Merat, S., \& Almuhtadi, W. (2015). Standard Arpu Calculation Improvement Using Artificial Intelligent Techniques. International Journal on Smart Sensing and Intelligent Systems, 8(4), 1917-1935.

[25]. Ariyanti, S. (2014). Studi perencanaan jaringan long term evolution area jabodetabek studi kasus PT. Telkomsel. Buletin Pos dan Telekomunikasi, 12(4), 255-268. 